\title{
Staff Development in Primary Schools: A Survey from Tembisa, South Africa
}

\author{
Dr Welcome Mswazi Kubeka
}

Academic Development Centre, University of Johannesburg

Email: wkubeka@uj.ac.za

\section{Prof Cornelius Johannes White}

\author{
Department of Educational Studies, Tshwane University of Technology
}

Email: WhiteCJ@tut.ac.za

Doi:10.5901/mjss.2014.v5n27p683

\begin{abstract}
Educators are faced with the responsibility of ensuring that they broaden and update their knowledge so that they can cater for the social welfare of learners as well as for their academic needs. Therefore staff development plays a key role in the upgrading of educators' knowledge and skills. The aim of this article is to describe the current situation regarding staff development at primary schools in Tembisa, based on research done in this regard. In the research both quantitative and qualitative approaches were used in order to ensure data triangulation. During data collection the researchers came into contact with educators at primary schools in Tembisa. Questionnaires were distributed and individual interviews were conducted with some principals. Three main findings of the research was that staff development is not regarded as a priority in all the schools, schools are not supported financially by the Department of Education to allow staff to attend staff development programmes and some facilitators of staff development programmes are not well trained, which mean that educators attending workshops do not always benefit maximally in improving their knowledge and skills.
\end{abstract}

Keywords: change management; curriculum; professional development; skills; staff development

\section{Introduction}

The changes in South Africa's educational system since 1994 and the introduction of various curricula such as Curriculum 2005 (1997), National Curriculum Statement (2002), Revised National Curriculum Statement (2004) and Curriculum Assessment Policy Statement (2012) has compelled educators to broaden and update their knowledge in order to teach more effectively. Continuous changes and new developments are continuously taking place in education, hence educators are expected to measure up to elevated levels of performance.

Campbell, McNamara and Gilroy (2004) argues that teaching today takes place in a world of rapid development and educators are expected to meet high standards of teaching and raise the levels of achievement in schools. To keep up with new developments educators are obliged to engage in staff development in order to stay in pace even abreast of change. Mestry and Singh (2007) believe that developing principals and providing them with the necessary knowledge, skills, values and attitudes becomes increasingly important because they have to set the pace in this continually changing environment. In this regards Chisholm (2000) notes that the training initiatives of the Department of Education (DoE) in developing and orientation of educators are inadequate to provide them with the desired skills in response to the changing needs of the curriculum. It is against this background that the study was conducted, with the aim of describing the current situation regarding staff development at primary schools in Tembisa.

Given all the educational changes that have taken place in the South African educational system through the introduction of policies related to staff development such as Developmental Appraisal System (DAS), Performance Management System (PMS), Whole School Evaluation (WSE) and Integrated Quality Management System (IQMS) educators are faced with the challenge of managing these educational changes in relation to their academic responsibilities. Hence, the need exists for staff development in order to prepare educators for continuous changes as the different roles they need to play accumulates day by day (DoESA, 2000).

In this article the following questions are addressed:

- What is the current situation regarding staff development at primary schools in Tembisa?

- What is the government policy on staff development in education? 
- What effect does the implementation of staff development programmes have on primary schools in Tembisa?

\section{Area Description for the Study}

South Africa is one of 55 states in the continent of Africa and is located at the southern tip of the continent. The country has an estimated population of about 51, 8 million people and its capital city is Pretoria (SSA, 2012). South Africa is divided into nine provinces, which are Eastern Cape, Free State, Gauteng, KwaZulu-Natal, Limpopo, Mpumalanga, Northern Cape, North West and Western Cape. Each province is further demarcated into municipalities and each municipality is made up of various cities with townships associated to each city. This study was conducted in Gauteng Province in a municipality called Ekurhuleni Metropolitan Municipality which is one of the 15 municipalities in Gauteng Province. Ekurhuleni Metropolitan Municipality has nine cities with their accompanied townships. Hence this study was conducted in Tembisa which city is Kempton Park.

The education system in South Africa is divided into two departments, that is, the Department of Basic Education and Department of Higher Education. The schools in South Africa are classified into primary and secondary which falls under the Ministry of Basic Education. The Further Education and Training Colleges and Universities are the responsibilities of the Ministry of Higher Education. The primary schools career consists of three phases, which are Foundation phase (Grades 1 -3), Intermediate phase (Grades $4-6$ ) and Senior phase (Grades 7 - 12). Even though grade 7 falls under the category of senior phase they are housed in primary schools.

The schools in each province are grouped into districts. In Gauteng Province there are 15 school districts under the jurisdiction of the Gauteng Department of Education. The 30 primary schools in Tembisa where this study was conducted fall under Ekurhuleni North, a district in Gauteng Department of Education.

\section{Research Methodology}

\subsection{Participants}

A population is the entire set of objects or people that are the focus of the research and about which the researcher wants to determine some characteristics (Bless \& Higson-Smith, 2000). The population for this study consisted of all 30 principals, 36 deputy principals, 111 heads of departments and 644 educators from the 30 primary schools in Tembisa.

\subsection{Sampling procedure and size}

For the quantitative sample, probability sampling was used in which every member of the population had a chance of being selected for the sampling (Wiersma, 2000). Probability sampling is based on the idea that the people who are chosen to form part of the sample are chosen because the researchers have some notion of the probability that this will be a representative cross-section of people in the whole population being studied (Denscombe, 2003). The number of staff members sampled were 447. According to Stoker (1985, as cited in Vermeulen, 1998) for a population of 821 the sample should be 100 , therefore a sample of 447 seemed appropriate, as it constitutes $54,4 \%$ of the population. The researchers used stratified random sampling to select the educators as participants (Du Plooy, 2001). There are 30 primary schools in Tembisa, from which the following subjects were drawn: 30 principals, 36 deputy principals, 111 heads of departments and 270 educators. The 270 educators were sampled through probability sampling using these strata: foundation phase educators 91, intermediate phase educators 112 and senior phase educators 67.

The researchers, in selecting sample for the qualitative part of this study, used purposive sampling. Purposive sampling indicates a selection of participants based on the characteristics of units, sites or individuals relevant to the research problem (Wiersma, 2000). For the research that formed the basis of this article, the criteria for the selection of participants were based on the teaching and management experience of the respondents and their proximity. For this research six principals from the primary schools in Tembisa were selected.

\section{Data Collection Method}

A questionnaire was used to collect quantitative data regarding biographical information and Likert-scales type items to determine perceptions about staff development among respondents. The Likert-scales type items were devised to determine the current situation regarding staff development at primary schools in Tembisa. Participants were asked questions on their current experiences regarding staff development at their respective schools. From the 447 distributed 
questionnaires, 316 were received back. This represents a $61 \%$ response rate, which was acceptable and enabled us to draw a valid and reliable conclusion. An interview schedule was developed to collect qualitative data from primary school principals. The questions asked during the interviews were aimed at determining participants' perceptions about staff development in schools.

\subsection{Reliability and validity of the research}

Triangulation combines quantitative and qualitative research approaches (Cooper \& Schindler, 2006). According to Cooper and Schindler (2006) the findings from qualitative and quantitative research may be combined to increase the perceived quality of research.

Denscombe (2003) states that in the classic meaning of reliability, the criterion of reliability is whether the research instruments are neutral in their effect, and would measure the same result when used on other occasions (applied to the same object). Reliability is a measure that gives the same answer when tested at different times and is concerned with consistency of measures (Du Plooy, 2001; Babbie \& Monton, 2002). To ensure quantitative reliability, the researchers piloted the questionnaire to a primary school. The reason for the piloting of the questionnaire to this selected primary school and not the schools where research was to be conducted was to avoid tainting the outcome. A tape recorder was used to record the interviews. The tape recorded interviews were transcribed and after that transcriptions were given to the participants to check whether they corresponded with what was said.

For Denscombe (2003) validity means that the data and methods are right. Validity holds the notion that the data reflect the truth and reality and cover crucial matters. He further mentions that validity addresses the questions, "Are we measuring suitable indicators of the concept and are we getting accurate results?" Babbie and Mounton (2002) mentions that validity refers to whether an instrument actually measures what it is supposed to measure given the context in which it is applied. In ensuring quantitative validity the questionnaire had the following characteristics, the questions were simple, brief and relevant to the problem; the number of questions were kept to the minimum and arranged in an orderly manner from simple to complex and simple language was used (McMillan \& Schumacher, 2000). To ensure qualitative validity the researcher conducted in-depth interviews in a natural setting to reflect the reality of the study. Questions in the interview schedule were phrased according to the participants' language proficiency and during the interviews, when the participants did not understand questions; the researchers explained to them so as to ensure mutual understanding between the interviewer and interviewee.

\subsection{Ethical considerations}

The purpose of the study was clearly explained to all participants and they were also informed that their participation was voluntarily. Confidentially and anonymity were assured during the data collection process. The permission for this study was obtained from the Gauteng Department of Education in South Africa.

\section{Results and Discussion}

\subsection{Findings based on quantitative data}

Section $\mathrm{A}$ of the questionnaire dealt with the biographical information of the respondents and frequencies and percentages were used to describe characteristics of the data. Table 1 gives an indication of the gender distribution of the respondents.

Table 1: Gender distribution of respondents

\begin{tabular}{lcr}
\hline Gender & Frequencies & Percentage \\
Female & 236 & 75 \\
Male & 80 & 25 \\
Total & 316 & 100 \\
\hline
\end{tabular}

According to Table 1, the majority of the respondents (75\%) were female and this could be due to the fact that the study was conducted in primary schools. This results are in line with the fact that in South Africa there are too many females than males. 
Table 2: Age of the respondents

\begin{tabular}{lcr}
\hline Age & Frequencies & Percentage \\
\hline Younger than 30 & 5 & 2 \\
$31-40$ yrs. & 119 & 38 \\
$41-50$ yrs. & 129 & 61 \\
51 yrs. and over & 63 & 20 \\
Total & 316 & 100 \\
\hline
\end{tabular}

Table 2 indicates the age of respondents. Data represented in Table 2 indicate that there were fewer respondents who are 30 years and younger (2\%) who participated in the study. The majority of respondents were older than 41 years (40\%). The figures in Table 2 further show that $60 \%$ of the respondents fell within the range of $41-51$ years and above, which suggest that, this was an experienced group of respondents in the teaching profession.

In Table 3, the positions of the respondents are indicated.

Table 3: Positions of respondents

\begin{tabular}{lcr}
\hline Positions & Frequencies & Percentage \\
\hline Principal and Deputy Principal & 60 & 19 \\
Head of Department & 62 & 20 \\
Educators & 194 & 61 \\
Total & 316 & 100 \\
\hline
\end{tabular}

The data outlined in Table 3 indicate that $39 \%$ of the respondents are in managerial positions, i.e. post levels two to four, which include principals, deputy principals and head of departments. The majority of respondents (61\%) occupy post level one positions, which include senior educators and educators. The ratio of Head of Department to educator is one to four, this means that there is a HOD for every four educators and given the demands of the new curriculum, this has a negative impact on the schools in relation to staff development, since head of departments have to manage a large number of subordinates.

Table 4: Teaching experience of respondents

\begin{tabular}{lcr}
\hline Teaching years & Frequencies & Percentage \\
$1-10$ years & 80 & 25 \\
$11-20$ years & 130 & 41 \\
$21-30$ years & 78 & 25 \\
31 years and more & 28 & 9 \\
Total & 316 & 100 \\
\hline
\end{tabular}

Table 4 indicates that, the majority of respondents (75\%) in the study had more than 15 years of teaching experience. This is of significance for this study because it means that the majority of respondents were trained long before the introduction of the new curriculum in 1997. This underlines the importance of staff development to upgrade the knowledge of the educators continuously to enable them to adapt to new ways of teaching since the curriculum have changed several times since the introduction of the Curriculum 2005 in 1997 after the beginning of the new democratic dispensation in South Africa in 1994.

In Table 5, the highest educational qualifications of respondents are indicated.

Table 5: Qualifications of respondents

\begin{tabular}{lcc}
\hline Qualifications & Frequencies & Percentage \\
\hline Grade 12 plus a Teachers' Diploma & 85 & 27 \\
Teachers' $^{2}$ Diploma and/or Further Education Diploma & 129 & 41 \\
Bachelors' Degree & 54 & 17 \\
Honours and/or Masters' Degree & 47 & 15 \\
Total & 316 & 100 \\
\hline
\end{tabular}


In Table 5 it can be seen that the largest group has teacher diplomas and further education diplomas (68\%). Respondents with bachelor degrees made up 17\%. A small percentage of the respondents (15\%) have honours and master's degrees. The norms and standards as outlined in the Committee on Teacher Education Policy (COTEP) document indicate that the educators need to demonstrate the role of being lifelong learners. Therefore the educators should develop the competencies of being familiar with current educational development and curriculum development (DoESA, 2000). The researchers agree that the educational qualifications of educators play a crucial role in the understanding of the curriculum content and terminology, hence the importance of staff development.

In Section B of the questionnaire the Likert-scale was used to describe the current situation regarding staff development at primary schools in Tembisa. The respondents were expected to indicate their responses according to the scales of 1. Strongly Agree (SA); 2. Agree (A); 3. Disagree (D) and 4. Strongly Disagree (SD). The following are the themes that were identified as significant:

The involvement of educators in staff development

Table 6: Educators involvement in staff development

\begin{tabular}{lccccc}
\hline Variable & Total & SA (\%) & A (\%) & D (\%) & SD \\
$\begin{array}{l}\text { In my school educators are involved in designing } \\
\text { staff development programmes }\end{array}$ & 316 & 20 & 9 & 17 & 54 \\
\hline
\end{tabular}

Responses to this statement revealed that the majority of the educators in the study (71\%) did not agree that staff members are involved in designing staff development programs (SDPs). Educators not being involved in designing SDPs may lead to the designed SDPs not addressing the needs of the school. According to the argument posed by Baloyi (2005), a staff development programme of good quality is an important avenue for updating and expanding educators' knowledge and skills and it built on the strengths that educators already have, hence their involvement is important.

Policy on staff development

Table 7: Government policy on staff development

\begin{tabular}{lllllr}
\hline Variable & Total & SA (\%) & A (\%) & D (\%) & SD \\
$\begin{array}{l}\text { In my school educators are awvare of government } \\
\text { policy on staff development }\end{array}$ & 316 & 22 & 56 & 18 & 4 \\
\hline
\end{tabular}

According to Table 7, the majority of respondents (78\%) agreed that in their schools' educators are aware of the government policy on staff development whereas, $22 \%$ of the respondents indicated that in their schools educators are not aware of the government policy on staff development. This may lead to educators resisting change because of misinformation or poor communication. This happens despite the argument posed by Nkabinde (2006), that the staff development policy should be a written document stating the direction the school is aiming to take so as to empower educators with skills and knowledge. In drafting the policy document, all participants' areas of concern should be taken into account. Involving everybody will ensure that the policy or decisions are respected.

Educators' formal training

Table 8: The linking of staff development with educators' formal training

\begin{tabular}{lccccc}
\hline Variable & Total & SA (\%) & A (\%) & D (\%) & SD \\
$\begin{array}{l}\text { In my school staff development is linked } \\
\text { with educators' formal training }\end{array}$ & 316 & 27 & 11 & 14 & 48 \\
\hline
\end{tabular}

The majority of respondents (62\%) in Table 8 agree that in their schools' staff development is not linked with educators' formal training. This is bound to have a negative impact on educators' best teaching practices, since educators are unable to implement the curriculum as expected. In this regard Grobler, Warnich, Carrel, Elbert and Hatfield (2002) state that the purpose of staff development is to improve employees' performance, update their skills and avoid managerial obselence. They further mention that its purpose is to solve organizational problems; to be used for the orientation of new employees; to prepare for promotion and managerial succession and to satisfy personal growth. 
The impact of staff development on teaching and learning

Table 9: Impact of staff development on teaching and learning

\begin{tabular}{lccccc}
\hline Variable & Total & SA (\%) & A (\%) & D (\%) & SD \\
$\begin{array}{l}\text { In my school staff development is } \\
\text { effectively implemented }\end{array}$ & 316 & 17 & 50 & 24 & 9 \\
\hline
\end{tabular}

From the data in Table 9, it can be concluded that the (67\%) of respondents agreed that in their schools, staff development is effectively implemented. It also indicates that 33\% are not satisfied with the implementation of staff development programmes. This is a matter of concern, since the ineffective implementation of staff development in schools could have a detrimental effect on educators' performance, as highlighted by Rebore (2001), who argues that continuous staff development will make staff members more knowledgeable with regard to new developments and changes in educators' fields of specialization and encourage them to use new, improved materials in practice.

Management of change

Table 10: Educators' management of change

\begin{tabular}{lccccc}
\hline Variable & Total & SA $(\%)$ & A (\%) & D (\%) & SD \\
$\begin{array}{l}\text { Staff development programmes have helped me } \\
\text { to be prepared for changes in my work }\end{array}$ & 316 & 16 & 4 & 18 & 62 \\
$\begin{array}{l}\text { In my school the leadership style of the SMT influences } \\
\text { the level of resistance to change }\end{array}$ & 316 & 11 & 31 & 47 & 11 \\
\hline
\end{tabular}

Table 10 indicates that the (80\%) of respondents disagreed that the SDPs have prepared them for changes in their work. Educators are expected to attend developmental programmes such as workshops and training to keep up with educational knowledge in the learning areas. If SDPs do not help educators to be prepared for changes in the work environment, it has a negative impact, as highlighted by Soler, Craft and Burgess (2001) who argue that well-educated, flexible, highly competent educators are required to handle curriculum changes that make multiple demands on them (educators), and foster practices responsive to the educational needs of all learners.

The data in Table 10 further revealed that $42 \%$ of the respondents claimed that in their schools, the leadership style of the School Management Team (SMT) influences the level of resistance to change. According to Van Der Westhuizen et al (2002) the principal as the leader of the SMT and a change agent has to accept the entire responsibility for managing change in a school, hence he or she is expected to initiate change, to facilitate it and to implement it.

\subsection{Findings based on qualitative data}

From the responses, based on the interview questions, the following themes could be identified. (Quotations were given verbatim so that the danger of misquoting was reduced).

\subsubsection{Theme 1: Staff development}

Participants' understanding of staff development varied. According to one respondent, staff development is a process through which educators are continuously developed so that they can acquire new knowledge and skills. The same respondent mentioned that "new ideas should be given to educators because knowledge is always developing." The empowerment of educators to do their day-to-day work better, was another aspect indicated by respondents. Respondents' understanding of staff development are in line with the point mentioned by Van Deventer and Kruger (2003) that staff development is essential in a time of rapid change. Educators need to keep abreast of new developments in education in general, as well as in their own field of expertise. Continued training will enhance their skills and enable them to sustain the new demands in the teaching fraternity.

\subsubsection{Theme 2: Policy on staff development}

It emerged from the responses received that circulars and memoranda are used in schools to make educators aware of 
the schools' staff development policy. One of the respondents mentioned that "...he (the principal) gives circulars to educators and make them to sign for them." An analysis of the verbatim responses of the participants revealed that in schools there is no policy on staff development issued by the DoE. Hence a participant mentioned that "we do not have a staff development policy from the Department of Education, but we do have a copy of IQMS." The findings emanating from the data revealed that educators are involved in staff needs analysis and identification. Hence one respondent mentioned that "when we do a SWOT analysis, educators do take part, we check every educator's strengths and weaknesses and then we form the base of our staff development." The non-availability of a detailed staff development policies in Tembisa primary schools is an area of concern. The staff development policy should be a written document stating the direction the school is aiming to take so as to empower educators with skills and knowledge Nkabinde (2006). Hence in drafting the policy document, all participants' developmental needs should be taken into account. Involving everybody will ensure that the policy or decisions taken are agreed upon.

It is clear that educators through IQMS identify areas which they need to be developed on. Steyn and Van Niekerk (2002) mentions that the purpose of professional development is to promote learning processes that will in turn enhance the performance of individuals and the organisation as a whole. They further mention that organisational development can be planned from the perspective of correcting shortcomings and creating opportunities for development. What really disturb is that although educators indicate throughout the year areas in which they need developmental nothing is done about that. One of the respondents mentioned that "... every year we identify areas which we need to be developed on as per our needs assessments but there is no follow up by the department of education officials".

\subsubsection{Theme 3: Teaching and learning}

Some of the respondents highlighted that SDPs affect teaching and learning positively. Some believe that staff development contributes positively to their teaching, whereas others feel it is a waste of time. As one respondent stated, "... some educators will go to attend workshops. When they come back they are motivated, they will be knowledgeable and skilled." Another respondent said that "... some educators will come back from the workshop and they will say they are empty." It was mentioned that staff development has a positive impact on teaching and learning, since educators learn to do their work effectively. One respondent indicated that "educators are able to work together especially as a team." Several participants pointed out that SDPs also contributed to the improvement of learners' performance. As mentioned by one respondent 'to a certain extent learners' performance has improved, although there is still room for more improvement and I have seen learners improving in what they are doing, especially when it comes to reading and writing." Some of the respondents agreed with Guskey (2002) who suggests that educators take part in continuous professional development because they believe it will make them better teachers and this will ultimately enhance learners' performance.

\subsubsection{Theme 4: Attitudes of educators to staff development}

During the interviews it became clear that some participants have a negative attitude towards workshops and they always complain about administrative work that needs to be done. As one respondent said "... educators will always complain about the paper work and when they come back from the workshops, educators will say there is a lot of paper work that need to be done." Another respondent indicated that "educators see staff development as a waste of time and makes educators to lose focus towards what they are really supposed to do at school." The respondents identified shortcomings in the abilities of subject facilitators. One respondent indicated that "the district office, sometimes send subject facilitators who are empty and who knows nothing and you attend a workshop and you find that the subject facilitator is not so good." A respondent mentioned that there is no support from the district office. The same respondent said "the problem is that sometimes because of the limited resources, the Department will say they are unable to run staff development programmes, since they are under-staffed and under-resourced." It was further mentioned that "the Department will say schools should source money somewhere so that the school will run the programme on their own." It is evident from these responses that in attending training courses is characterised by fragmented workshops at which educators listen passively to subject experts and learn about topics not essential to teaching (Boyle, White \& Boyle, 2004). According to Day and Sachs (2004) such short term "spray-on continuous professional development" fails to change educators' competence and practice, or their fundamental beliefs about teaching. 


\subsubsection{Theme 5: Role of the School Management Team}

One of the respondents highlighted that the role of the SMT with regard to staff development is to ensure that programmes are being implemented by educators. Hence he said "always there is a timetable that is being followed and there is feedback from the HODs, deputy principal and the principal. The SMT always come together to see whether we are on the right track." It became evident from the statements of respondents that the SMT supports educators by getting information for them. It was mentioned that "we try to help educators on how to work with those learners who have learning barriers. In addition the SMT empowers educators." The respondents indicated that schools encourage educators to further their studies. From the responses it became clear that the SMT is committed to support educators. As one of the respondents said "... for now is the time to do requisition for the next year and educators will write down all the necessary learning material and resources which they will need that will enhance their development." Salfi (2011) in his study points out that the majority of the head teachers of successful schools at Pakistan developed a common and shared vision and promoted a culture of collaboration, support and trust. They empowered others to lead and distributed leadership responsibilities throughout the school, to involve different stakeholders in the process of decision making, to develop and maintain good relationships among different personnel of school community. They emphasised the professional development of teachers as well as themselves and involved parents and the community in the process of school improvement. It is argued by Moye, Henkin and Egley (2005) that in United States of America (USA), lowa, that those teachers who perceived that they were empowered in their work environments had higher levels of interpersonal trust in their principals. Teachers who found their work personally meaningful, and who reported significant autonomy and substantial influence in their work environments had higher levels of interpersonal trust in principals.

\section{Conclusion}

This article dealt with the current situation regarding staff development at primary schools in Tembisa. Nkabinde (2006) states that a staff development policy should be a written document stating the direction the school is aiming to take so as to empower educators with skills and knowledge. In drafting the policy document, all participants' areas of concern should be taken into account. Involving everybody will ensure that the policy or decisions taken are respected. It can be concluded that there is no available clear policy on staff development at primary schools in Tembisa. This has led to schools using IQMS as a basis for staff development. The lack of a policy on staff development has also resulted in educators with no common understanding of the concept staff development.

The DoE fails to provide financial support to schools for SDPs. Schools are sometimes requested by the DoE to finance their own SDPs, such as workshops, from their own school coffers and this puts schools in a tenuous position, since not all parents pay the required school fees. Lack of financial support from the DoE also has a negative impact on learners' performance, since educators cannot attend crucial SDPs. The researchers came to the conclusion that the DoE has no well-designed, detailed plan or schedule for staff development. The DoE takes no action at schools in relation to the identified individual school needs in respect of the IQMS process. This lack of planning in respect of SDPS hampers educators' professional development. This compels the DoE to provide generic SDPs to schools that are not beneficial to some of the schools, since their individual needs are not catered for. The conclusion that can be drawn from this study is that subject facilitators are not well trained in their specific areas. This has a negative impact on learners' academic performance and educators in general since they (subject facilitators) are not equipped to support educators. Educators perceive SDPs, such as workshops that are facilitated by subject facilitators, as a waste of time, since they (subject facilitators) cannot address their concerns in relation to the subject content. Hence the educators feel powerless and frustrated because they derive no value in terms of their academic development.

\section{References}

Babbie, E., \& Monton, J. (2002). The practice of social research. Cape Town: Oxford University Press.

Baloyi, S.T. (2005). Developmental appraisal system in schools within the Temba area project office. MTechEd. Dissertation. Pretoria: Tshwane University of Technology.

Bles, C., \& Higson-Smith, C. (2000). Fundamentals of social research methods: An African perspective. (3rd ed.). Cape Town: Juta \& Co.

Boyle, B., White, D., \& Boyle, T. (2004). A longitudinal study of teacher change: What makes professional development effective? Curriculum Journal, 15, (1), 45-48.

Campbell, A., McNamara, O., \& Gilroy, P. (2004). Practitioner research and professional development in Education. London: Paul Chapman Publishing.

Chisholm, L. (2000). A curriculum for the $21^{\text {st }}$ century: Report of the review committee on curriculum 2005. Pretoria: Department of 
Education.

Cooper, D.R., \& Schindler, P.S. (2006). Business research methods. New York: McGraw-Hill.

Day, C., \& Sachs, J. (2004). Professionalism, performativity and empowerment: Discourses in the politics, policies and purposes of continuing professional development. In C. Day., \& J. Sachs (Ed.). International handbook on the continuing professional development of teachers, (pp. 3-32). Maidenhead: Open University Press.

Denscombe, M. (2003). The good research guide: For small-scale social research projects. (2nd ed.). Philadelphia: Open University Press.

DoESA. (Department of Education South Africa). (2000). Instructional leadership guide. South African Government: South Africa.

Du Plooy, G.M. (2001). Communication research: Techniques, methods and applications. Lansdowne: Juta.

Grobler, P.A., Warnich, S., Carrell, M.R., Elbert, N.F, \& Hatfield, R.D. (2002). Human resource Management in South Africa. (2nd ed.). United Kingdom: Cornwall.

Guskey T.R (2002). Professional development and teacher change: Teachers and teaching. Theory and practice, 8 (3), $381-391$.

Mampuru, K.C. (2001). Educational management. Pretoria: Tshwane University of Technology.

McMillan, J.H, \& Schumacher, S. (2000). Educational research: Fundamentals for the consumer. New York: Longman.

Mestry, R., \& Singh, P. (2007). Continuing professional development for principals: A South African Perspective. South African Journal of Education, 27, (3), 477-490.

Moye, M.J., Henkin, A.B., \& Egley, R.T. (2005). Teacher-principal relationships: Exploring linkages between empowerment and interpersonal trust. Journal of Educational Administration, 43, (3), 260-277.

Nkabinde, A.P. (2006). The role of staff development programmes in improving the performance of educators in Delmas secondary schools. Med. Dissertation. Johannesburg: University of Johannesburg.

Rebore, R.W. (2001). Human resources administration in education: A management approach. Boston: Allyn and Bacon.

Salfi, N.A (2011). Successful leadership practices of head teachers for school improvement: Some evidence from Pakistan. Journal of Educational Administration, 49, (4), 414-432.

Soler, J., Craft, A., \& Burgess, H. (2001). Teacher development: Exploring our own practice. London: Paul Chapman in Association with the Open University Press.

SSA (Stats South Africa). (2012). South African Statistics. Pretoria: Government Printers

Steyn, G.M., \& Van Niekerk, E.J. (2002). Human resource management in education. Pretoria: University of South Africa.

Van Deventer, I., \& Kruger, A.G. (2003). An educator's guide to school management skills. Pretoria: Van Schaik Publishers.

Van der Westhuizen, P.C., Bruyn, P.P., Erasmus, M., Janson,C.A., Mentz, P.J., Steyn, S.C., \& Theron, A.M.C. (2002). Schools as organisations. (2 ${ }^{\text {nd }}$ ed.). Pretoria: Van Schaik Publishers.

Vermeulen, L.M. (1998). Research orientation: A practical study guide for students and researchers. Pretoria: Technikon Pretoria.

Wiersma, W. (2000). Research methods in education: An introduction. San Francisco: Library of Congress Cataloguing-in-Publication data. 